\title{
FINITE ELEMENT MODELING OF CIRCULAR REINFORCED CONCRETE COLUMN CONFINED WITH CFRP UNDER ECCENTRIC LOADING
}

\author{
Angga Bayu Christianto ${ }^{\mathrm{a}}$, Bambang Piscesa ${ }^{\mathrm{b}^{*}}$, Faimun Faimun ${ }^{\mathrm{b}}$, Pujo Aji ${ }^{\mathrm{b}}$
}

\begin{abstract}
This paper presents nonlinear finite element analysis of eccentrically loaded circular Reinforced Concrete (RC) column confined with Carbon Fiber Reinforced Polymer (CFRP) wraps. The concrete constitutive model uses a plasticityfracture model which is restraint sensitive, utilize a non-constant plastic dilation rate, and is able to simulate the plastic volumetric compaction of concrete core under high confining pressure. For validation of the models, two available specimens from the literature are used in the validations. Excellent agreement between the numerical models and the available test results are obtained in this study. A detailed investigation on the confinement effectiveness of both external and internal confining devices are presented and discussed. This discussion of the confinement effectiveness is important to be included in the design formula.
\end{abstract}

Keywords: Carbon Fiber Reinforced Polymer, Confinement, Eccentric loading, Reinforced Concrete Column

\section{INTRODUCTION}

Reinforced concrete structures have been widely used as public facilities and infrastructure such as buildings, bridges, and etc. These structures, in time, may have its function changed or exhibits reduced load carrying capacity of its structural element caused by material deterioration or due to an extreme load event such as earthquake. Updates in the building code requirements for a ductile structure can also requires existing building to be strengthened or retrofitted if necessary.

The strength and ductility capacity of RC columns can be enhanced by providing external confinement to the concrete core. There are several ways to provide these external confinements such as reinforced concrete jacketing, steel jacketing, and Fiber Reinforced Polymer based jacketing/wrapping [1]. However, choosing the appropriate type of external confining device depends on many factors. Each confining device has its advantages and disadvantages. Hence, choosing a proper material to strengthen existing RC columns is not only depends on the strength and ductility requirements but also on the environmental conditions. In this paper, the study on the use of external confinement is limited to RC columns wrapped with Carbon Fiber Reinforced Polymer (CFRP).

Carbon Fiber Reinforced Polymer (CFRP) jacketing / wrapping is a reinforcement technique that is often used to strengthen reinforced concrete column elements [2-4]. Extensive investigations have been conducted on the compressive behavior of carbon fiber reinforced polymer (CFRP) confined columns [2, 5-7]. The use of CFRP jacketing as a lateral Confinement can increase the strength and ductility of reinforced concrete columns [8-12]. In addition, CFRP is a lightweight material, that has a high tensile strength, and is easy to implement in the field [13]. Carbon fiber polymer-based material does not corrode at room temperature, and thus increase the effectiveness of CFRP as the external confining devices. The use of CFRP strengthened system have been proven to increase the strength capacity and ductility of RC elements to carry bending, shear, and axial loads [14].

${ }^{a}$ Master Student in the Civil Engineering Department, Institut Teknologi Sepuluh Nopember, ITS Campus, Sukolilo, Surabaya 60111, Indonesia.

${ }^{b}$ Lecturer in the Civil Engineering Department, Institut Teknologi Sepuluh Nopember, ITS Campus, Sukolilo, Surabaya 60111, Indonesia. Corresponding author email address: piscesa@ce.its.ac.id
Most existing CFRP strengthening guidelines can be applied only to columns under concentric axial loads although a few notable exceptions have appeared in recent years [15]. In reality, concrete columns are often subjected to eccentric loads and may be susceptible to instability resulting from their slenderness [16].

Research on the behavior and usage of CFRP material to confine the concrete core have been carried out by many researchers [17-23]. Teng and his coworkers have been working closely to study the behavior of concrete confined with FRP. One of his recent studies [24] examined RC columns confined with CFRP under pure concentric loadings. However, his model was shown to underestimate the load-deflection curve of the test results. In contrary with the concrete constitutive model proposed by Piscesa and his coworker's [1], Piscesa's model, which was shown to be in close agreement with the test results and was able to capture the effective confinement area and the lateral modulus value provided by both the internal and external confining devices.

In 2017, Lin et. al. [25] uses Teng's model to simulate the behavior of CFRP confined RC columns under eccentric loadings. Since in the previous works, the authors have not yet considered eccentric loading behavior of CFRP confined RC column. Significant experimental investigations on eccentrically loaded CFRP confined columns have been reported [4, 17, 26-32]. In this paper, a similar work carried out by Lin et. al. [25] is performed, but using the Piscesa's et. al. model [1, 33-36]for the concrete constitutive model. The focus is not only on the comparisons of the load-deflection curve between the model and test results, but also in the distribution of confining pressure, hardening parameters, fracturing region of concrete (when in tension), and the lateral modulus of both internal and external confining devices. For that purposes, 3D-NLFEA package which was developed by $[1,33,35,37]$ is used.

\section{RESEARCH SIGNIFICANCE}

This paper investigates the behavior of eccentrically loaded CFRP confined RC columns by using nonlinear finite element method. The concrete constitutive model used can capture the effect of restraint sensitiveness, has a non-constant plastic dilation rate, and is able to capture the plastic volumetric compaction behavior of concrete 
material. Detailed discussion on the effectiveness of confinement is also presented.

\section{METHODOLOGY}

The research methodologies of this paper are divided into several stages. The first stage discusses on how to model the specimens in SALOME 9.3.0. These modeling stage includes the specimen geometry details, boundary conditions modeling and detailed input data for the concrete constitutive model. In the second stage, a detailed discussion of the analysis results which contains the lateral modulus contours distributions at each important step are presented. At the third stage, discussion on the comparisons between the experimental and analysis results are discussed in detail. Finally, conclusions are drawn which conclude the performance of the used concrete constitutive models.

\section{A. SPECIMENS DETAILS AND MODELING IN SALOME 9.3.0}

To model the column specimens in $3 \mathrm{D}$, SALOME platform [38] was used as the preprocessor. In this study, two circular RC column specimens available in the literature (Bisby and Ranger [32]) are modelled. The selected specimens have load eccentricities of 5 and 20 $\mathrm{mm}$. The specimens have a diameter of $152 \mathrm{~mm}$ and a height of $608 \mathrm{~mm}$. The FRP material have a thickness of $0.38 \mathrm{~mm}$, elastic modulus of $90 \mathrm{GPa}$, and ultimate tensile strength of $933 \mathrm{MPa}$. The concrete compressive strength is set to $33.2 \mathrm{MPa}$. The columns are reinforced in the longitudinal direction with four deformed longitudinal rebars with a diameter of $6.4 \mathrm{~mm}$. The internal confining device is provided by circular steel hoops with a diameter of $6.4 \mathrm{~mm}$ spaced at $100 \mathrm{~mm}$ measured from center-tocenter of the hoops. The steel reinforcing bar have a yield strength of $710 \mathrm{MPa}$. The detailed information of the specimen is provided in Table 1 .

Table 1. CFRP-Confined Concrete Columns under Eccentric Loading.

\begin{tabular}{ccc}
\hline \multirow{2}{*}{ Notations } & \multicolumn{3}{c}{ Specimens ID } \\
\cline { 2 - 3 } & $\mathrm{C} 5$ & $\mathrm{C} 20$ \\
\hline $\mathrm{D}(\mathrm{mm})$ & 152 & 152 \\
$\mathrm{~L}(\mathrm{~mm})$ & 608 & 608 \\
$\mathrm{t}_{\mathrm{f}}(\mathrm{mm})$ & 0.38 & 0.38 \\
$\mathrm{~d}(\mathrm{~mm})$ & 6.4 & 6.4 \\
$\mathrm{n}$ & 4 & 4 \\
$\mathrm{~s}(\mathrm{~mm})$ & 100 & 100 \\
$\mathrm{e}(\mathrm{mm})$ & 5 & 20 \\
$\mathrm{f}_{\mathrm{c}}(\mathrm{MPa})$ & 33.2 & 33.2 \\
$\mathrm{f}_{\mathrm{y}}(\mathrm{MPa})$ & 710 & 710 \\
$\mathrm{E}_{\mathrm{f}}(\mathrm{GPa})$ & 90 & 90 \\
\hline
\end{tabular}

* Notes: $\mathrm{d}=$ diameter of longitudinal/transverse steel bars; $\mathrm{n}=$ number of longitudinal steel bars; $\mathrm{s}=$ hoops pitch spacing; $\mathrm{e}=$ initial load eccentricity; $\mathrm{f}^{\prime} \mathrm{c}=$ concrete cylinder compressive strength; fy $=$ yield stress of longitudinal/transverse steel bars; $\mathrm{t}_{\mathrm{f}}, \mathrm{E}_{\mathrm{f}}=$ nominal thickness and elastic modulus of CFRP jacket from coupon tensile tests or manufacturer's data.

Figure 1 shows the specimen's side view and its cross section. In Figure 1(a), both top and bottom ends is reinforced with a $25 \mathrm{~mm}$ thick steel plate with the purpose was to distribute the eccentric load from the plate to the concrete elements. Figure 1(b), shows the reinforcing bar arrangement for both the longitudinal and transverse rebars. Figure 1(c) shows the schematic loading of the specimens. The load is given as a displacement applied at a line at the top end while at the bottom, a restraint boundary condition is sought.

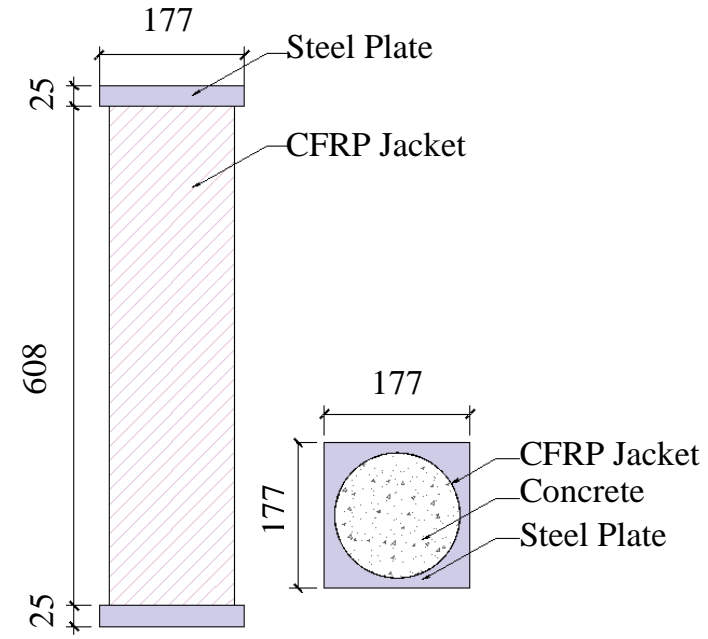

(a)
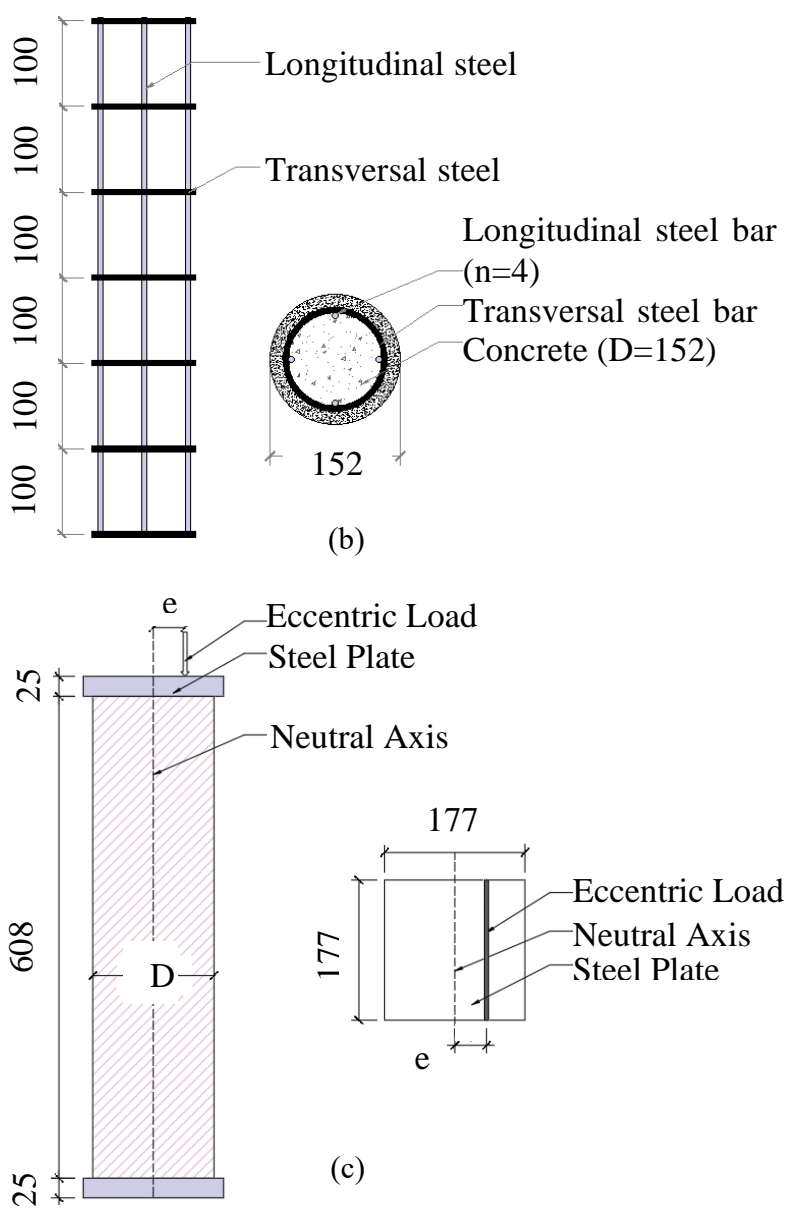

Figure 1. Side view and cross section of (a) solid elements, (b) rebar elements and (c) schematic eccentric load

The concrete compressive strength and modulus of elasticity are 33.2 MPa and 27,081 MPa, respectively. The modulus elasticity of the steel reinforcement and the steel plate is $200 \mathrm{GPa}$. The steel plate is set to have sufficiently 
high yield stress to avoid yielding due to stress concentration at the knife edge load. The yield stress of both the longitudinal and transverse reinforcing bars is set to $710 \mathrm{MPa}$. For the CFRP materials, the elastic modulus and yield strength are $90 \mathrm{GPa}$ and $933 \mathrm{MPa}$, respectively.

Figure 2 shows the specimen 3D model meshed in SALOME 9.3.0. The total number of nodal points and solid elements are 39,088 and 42,060, respectively. Figure 2(a) shows the meshed concrete elements only. Figure 2(b) shows the meshed CFRP elements only. Note that the CFRP elements are also modelled using solid 3D hexahedral element. Figure 2(c) shows the meshed rebars elements. The rebars are modelled using embedded truss elements. Figure 2(d) shows the full meshed element of the specimens. The boundary condition at both ends are set to fixed in all directions. The load is given using displacement control at the top of the columns with the edge element it can moved with different eccentricities as shown in Figure 1(c). The displacement increment for each time step is set to $-0.01 \mathrm{~mm}$ (downward direction).

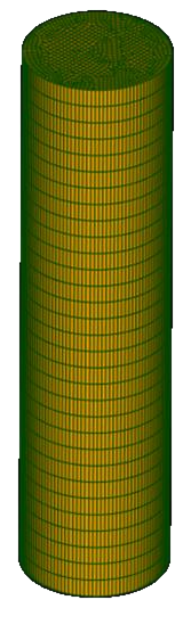

(a)

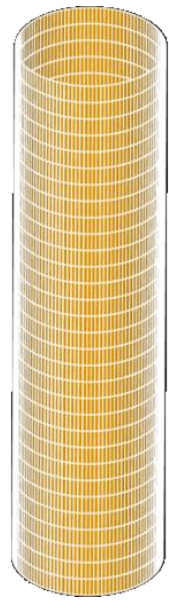

(b)

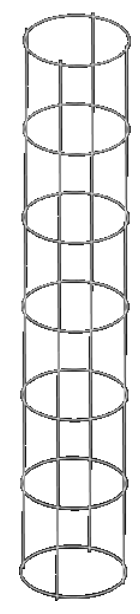

(c)

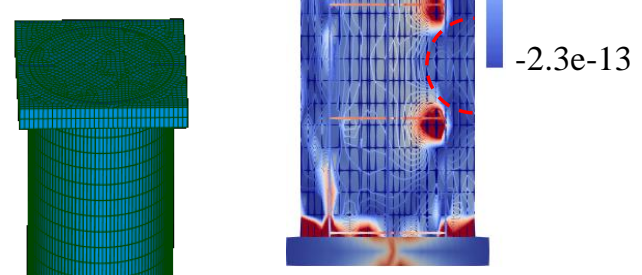

Figure 3. The $\mathrm{C} 5$ specimen volume with the EL contour at elastic stage
Figure 2. Specimen meshed model of a typical column under eccentric loading in SALOME: (a) concrete, (b) CFRP jacket, (c) reinforcing bars and (d) full model of the specimen

\section{B. ANALYSIS RESULTS ON THE LATERAL MODULUS CONTOUR DISTRIBUTION AND DISCUSSIONS}

To understand more about the confinement effectiveness, a lateral modulus in the concrete elements should be computed. For an actively confined concrete, where the confining pressure is constant, the value for the lateral modulus is zero. On the other hand, for passively confined concrete, the value for lateral modulus varies depends on the concrete dilation rate, the presence of confining pressures, and the stiffness of the confining devices $[1,33,35,36]$. In this study, there are two regions looked in the details. The first region is in the elastic region. In the elastic region, the transverse steel reinforcing bars are not yet yielded. Hence, both the CFRP and the transverse steel reinforcing bars are working together.

Figure 3 shows the lateral modulus of the C5 specimen at the vertical cross section and the 3D surface contour of the lateral modulus. As shown in Figure 3, high values of lateral modulus are found at the ties in the concrete under compression zones. This clearly indicates that the stiffness of the ties is concentrated and is higher than the CFRP wraps. The value of the lateral modulus also higher at the inner concrete core than at the outer concrete core. This can be easily identified as the inner concrete core is confined by both the transverse steel and the CFRP wraps.
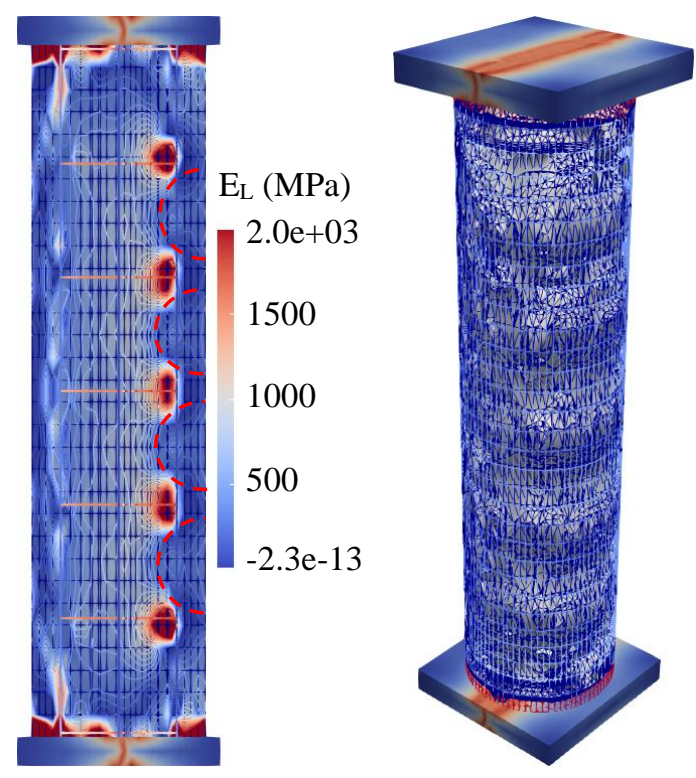

On the other hand, the outer concrete core only modulus value will gives different values of the concrete dilation rate. At the inner core, the concrete dilation rate is much lower than the concrete at the outer core. Hence, it will creates a negative effect at the outer concrete core [24]. the lateral modulus also clearly visible and is marked with a red dashed line. This arching action only visible in the compression region of the concrete elements.
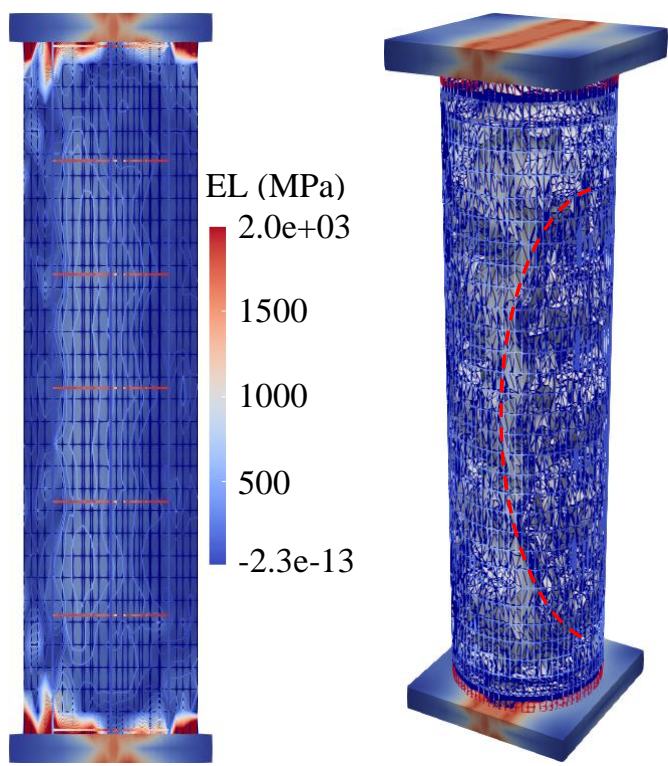

Figure 4. The C5 specimen volume with the EL contour confined by CFRP wraps. This difference in the lateral In addition, it is seen from Figure 3 that arching action on after the circular ties is yield 
Figure 4 shows the lateral modulus contour of C5 specimen both at the vertical cross section and in $3 \mathrm{D}$ view when the ties yield. As shown in Figure 4, the concentration of lateral modulus at the ties is disappearing. Moreover, rather than having an arching action between the ties, the arching action become larger and is occurring only at the compression region of the concrete. The values of the lateral modulus at this region is also low which clearly shows a negative effect of the difference in the generated plastic dilation rate at the concrete inner core and the concrete outer core.

Figure 5 shows the $\mathrm{C} 20$ specimen lateral modulus contour and its 3D volume of the lateral modulus at the elastic stage while Figure 6 shows the same properties but at the condition where the steel ties is already yielded. As shown in Figure 5 and Figure 6, the same conclusions as in specimen $\mathrm{C} 5$ are obtained.
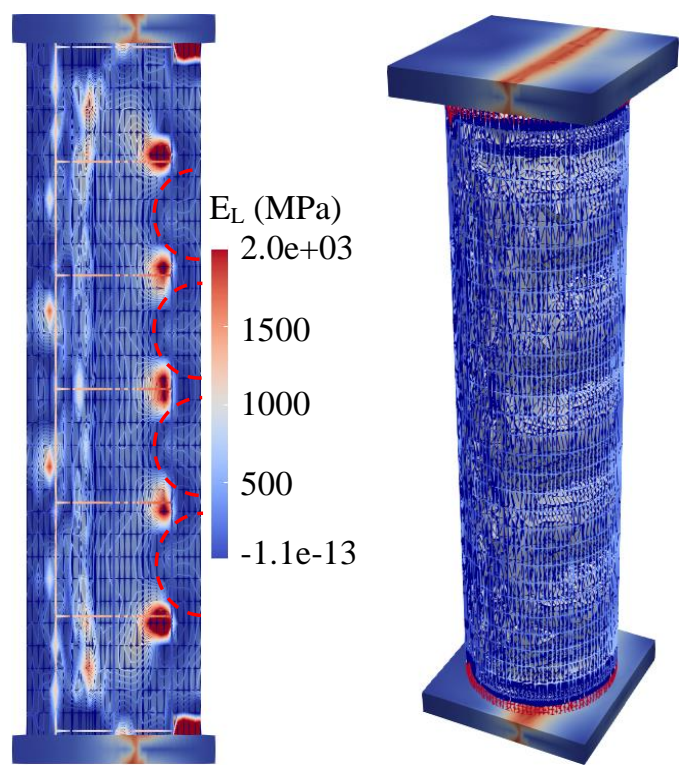

Figure 5. The C20 specimen volume with the EL contour at elastic
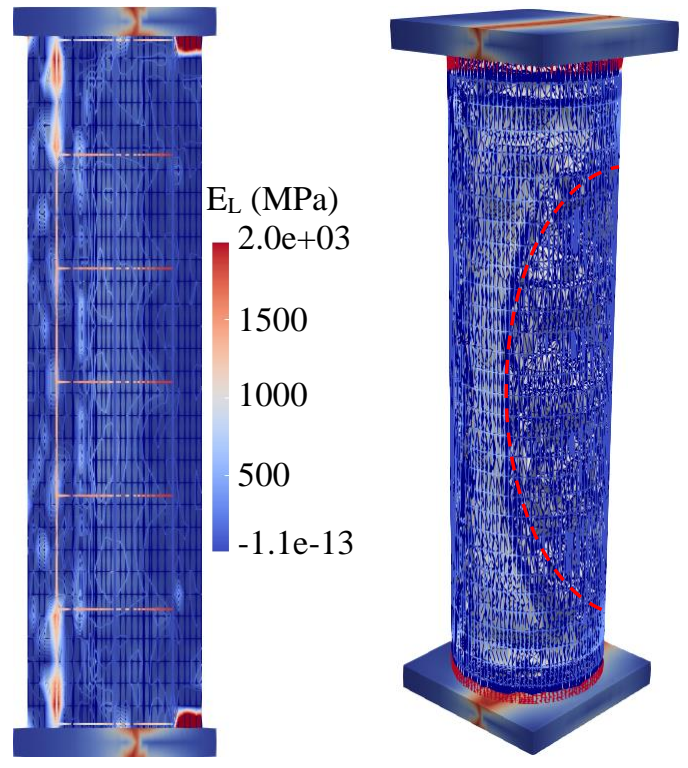

Figure 6. The C20 specimen volume with the EL contour after the circular ties is yield

\section{COMPARISONS OF AXIAL LOAD AS FUNCTION OF THE MID-HEIGHT LATERAL DISPLACEMENT}

In this section, comparisons of the axial load carrying capacity of specimens C5 and C20 tested by Bisby and Ranger [32] are compared with the analysis results obtained in this paper using 3D-NLFEA and also with the analysis results carried out by Teng et. al. [25]. Figure 7 show the comparison of axial load as function of the midheight lateral displacement for specimen C5. As shown in Figure 7, the initial stiffness of the specimen from the test results is quite stiff. The model of [25] shows more softens initial response and the model from 3D-NLFEA was stiffer than [25] but still not as stiff as the experimental result. The hardening behavior of the test result and 3D-NLFEA is similar while for the analysis result from [25] showed higher hardening behavior. Figure 8 shows the comparison response for $\mathrm{C} 20$ specimen. Unlike specimen $\mathrm{C} 5$, the analysis results from 3D-NLFEA and [25] behaves almost similar and are in good agreement with the experimental results.

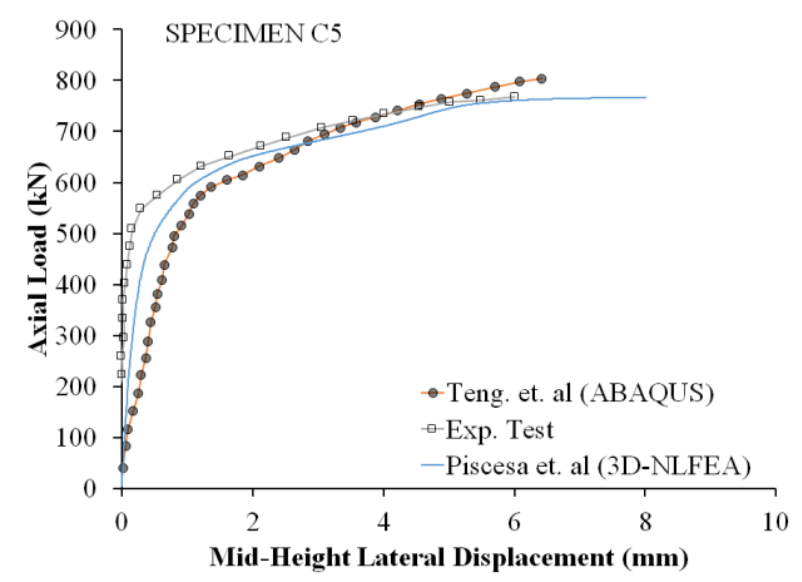

Figure 7. Comparison of axial load-lateral displacement curves of columns C5 with $5 \mathrm{~mm}$ load eccentricities.

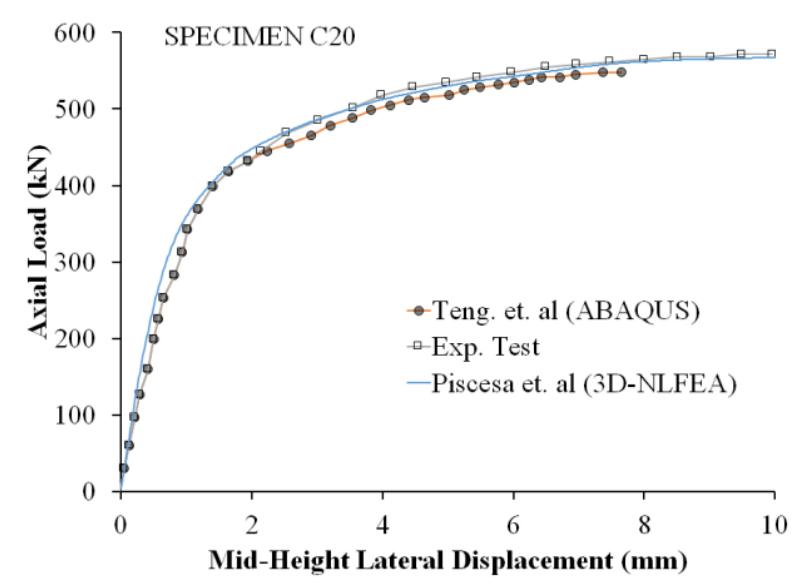

Figure 8. Comparison of axial load-lateral displacement curves of columns C20 with $20 \mathrm{~mm}$ load eccentricities.

From Figures 7 and 8, the effect of load eccentricities can be seen clearly. As the load eccentricity increased, the axial load carrying capacity of the column decreases. However, the decrease in axial load carrying capacity 
resulted in higher ductility. This can be easily understood as the mode of failure changes from axially dominated compression or compression controlled to the bending region or tension controlled. This observation has also been reported by many other researchers on both conventional RC columns and CFRP-confined concrete columns under eccentric loading (e.g., Scott et al. [39]; Fam et al. [40]; Yu et al. [41]; Csuka and Kollár [42]).

\section{CONCLUSIONS}

Two RC columns confined with CFRP under eccentric loading tested by [32] had been investigated. One of the interesting findings on the negative effect of confinement at the outer concrete region have been discussed. This negative confinement effect is caused by significant difference between the concrete dilation rate at the inner to the outer concrete core region. At the elastic stages, there is lateral modulus concentration at the hoops at the concrete under compression regions. After the steel yields, the lateral modulus concentration is disappearing. This can be attributed to the negative confinement effect.

From the comparison of the axial load carrying capacity as function of the mid-height lateral displacement showed that for small load eccentricities, the 3D-NLFEA analysis results showed stiffer initial response than the analysis results obtained by Teng et. al. [25] and is closer with the test results. However, as the load eccentricities increased from 5 to $20 \mathrm{~mm}$, both models performed almost similar. Further numerical simulation should be carried out to investigate the behavior of $\mathrm{RC}$ column confined with CFRP under eccentric loading. It also worth to investigate in detail on the confining pressure distribution in order to develops simplified approach for RC column confined with CFRP.

\section{REFERENCES}

[1] B. Piscesa, M. M. Attard, and A. K. Samani, "3D Finite element modeling of circular reinforced concrete columns confined with FRP using a plasticity based formulation," Composite Structures, vol. 194, pp. 478-493, 2018.

[2] J. Teng, J.-F. Chen, S. T. Smith, and L. Lam, "FRP: strengthened RC structures," Frontiers in Physics, p. 266, 2002.

[3] L. Hollaway, "Fibre-reinforced polymer (FRP) composites used in rehabilitation," in Strengthening and rehabilitation of civil infrastructures using fibre-reinforced polymer (FRP) composites: Elsevier, 2008, pp. 45-82.

[4] M. Hadi, "Behaviour of FRP wrapped normal strength concrete columns under eccentric loading," Composite Structures, vol. 72, no. 4, pp. 503-511, 2006

[5] G. Wu, Z. Wu, Z. Lu, and Y. Ando, "Structural performance of concrete confined with hybrid FRP composites," Journal of reinforced plastics and composites, vol. 27, no. 12, pp. 1323-1348, 2008.

[6] D.-S. Gu, Y.-F. Wu, G. Wu, and Z.-s. Wu, "Plastic hinge analysis of FRP confined circular concrete columns," Construction and Building Materials, vol. 27, no. 1, pp. 223-233, 2012.
[7] D.-S. Gu, G. Wu, Z.-S. Wu, and Y.-F. Wu, "Confinement effectiveness of FRP in retrofitting circular concrete columns under simulated seismic load," Journal of Composites for Construction, vol. 14, no. 5, pp. 531-540, 2010.

[8] Y. Xiao and H. Wu, "Compressive behavior of concrete confined by carbon fiber composite jackets," Journal of materials in civil engineering, vol. 12, no. 2, pp. 139-146, 2000.

[9] M. Samaan, A. Mirmiran, and M. Shahawy, "Model of confined concrete by fiber composites," ASCE Journal of Structural Engineering, vol. 124, no. 9, pp. 1025-1031, 1998.

[10] P. Rochette and P. Labossiere, "Axial testing of rectangular column models confined with composites," Journal of composites for construction, vol. 4, no. 3, pp. 129-136, 2000.

[11] A. Mirmiran, M. Shahawy, M. Samaan, H. E. Echary, J. C. Mastrapa, and O. Pico, "Effect of column parameters on FRP-confined concrete," Journal of Composites for construction, vol. 2, no. 4, pp. 175-185, 1998.

[12] K. A. Harries and G. Kharel, "Experimental investigation of the behavior of variably confined concrete," Cement and Concrete research, vol. 33, no. 6, pp. 873-880, 2003.

[13] B. Binici, "Design of FRPs in circular bridge column retrofits for ductility enhancement," Engineering Structures, vol. 30, no. 3, pp. 766776, 2008.

[14] L. A. Bisby, A. J. Dent, and M. F. Green, "Comparison of Confinement Models for FRP Wrapped Concrete," ACI Structural Journal, pp. 62-72, 2005.

[15] American Concrete Institute (ACI), "Design and construction of externally bonded FRP systems for strengthening concrete structures," $A C I$, vol. 440.2R-08, 2008.

[16] J. G. MacGregor and J. E. Breen, "Design of slender concrete columns," in Journal Proceedings, 1970, vol. 67, no. 1, pp. 6-28.

[17] Z. Tao, J. Teng, L.-H. Han, and L. Lam, "Experimental behaviour of FRP-confined slender RC columns under eccentric loading," in Advanced Polymer Composites for Structural Applications in Construction: Elsevier, 2004, pp. 203-212.

[18] V. Tamuzs, R. Tepfers, E. Zile, and V. Valdmanis, "Stability of round concrete columns confined by composite wrappings," Mechanics of Composite Materials, vol. 43, no. 5, pp. 445-452, 2007.

[19] A. Mirmiran, M. Shahawy, and T. Beitleman, "Slenderness limit for hybrid FRP-concrete columns," Journal of Composites for Construction, vol. 5, no. 1, pp. 26-34, 2001.

[20] T. Jiang and J. Teng, "Strengthening of short circular RC columns with FRP jackets: a design proposal," 2006.

[21] T. Jiang, "FRP-confined RC columns: analysis, behavior and design," The Hong Kong Polytechnic University, 2008. 
[22] J. Fitzwilliam and L. A. Bisby, "Slenderness effects on circular CFRP confined reinforced concrete columns," Journal of Composites for Construction, vol. 14, no. 3, pp. 280-288, 2010.

[23] L. De Lorenzis, V. Tamuzs, and R. Tepfers, "Stability of CFRP-confined columns," University of Lecce, Lecce, Italy, 2004, pp. 327342.

[24] J. Teng, Q. Xiao, T. Yu, and L. Lam, "Threedimensional finite element analysis of reinforced concrete columns with FRP and/or steel confinement," Engineering Structures, vol. 97, pp. 15-28, 2015.

[25] G. Lin and J. Teng, "Three-dimensional finiteelement analysis of FRP-confined circular concrete columns under eccentric loading," Journal of Composites for Construction, vol. 21, no. 4, p. 04017003, 2017.

[26] J. Li and M. Hadi, "Behaviour of externally confined high-strength concrete columns under eccentric loading," Composite Structures, vol. 62, no. 2, pp. 145-153, 2003.

[27] M. N. Hadi, "Behaviour of eccentric loading of FRP confined fibre steel reinforced concrete columns," Construction and Building Materials, vol. 23, no. 2, pp. 1102-1108, 2009.

[28] M. N. Hadi, "The behaviour of FRP wrapped HSC columns under different eccentric loads," Composite Structures, vol. 78, no. 4, pp. 560-566, 2007.

[29] M. N. Hadi, "Behaviour of FRP strengthened concrete columns under eccentric compression loading," Composite Structures, vol. 77, no. 1, pp. 92-96, 2007.

[30] M. N. Hadi, "Comparative study of eccentrically loaded FRP wrapped columns," Composite structures, vol. 74, no. 2, pp. 127-135, 2006.

[31] M. Hadi and J. Li, "External reinforcement of high strength concrete columns," Composite Structures, vol. 65, no. 3-4, pp. 279-287, 2004.

[32] L. Bisby and M. Ranger, "Axial-flexural interaction in circular FRP-confined reinforced concrete columns," Construction and Building Materials, vol. 24, no. 9, pp. 1672-1681, 2010.

[33] B. Piscesa, "Modeling confined concrete using plasticity formulation," PhD. Thesis, School of Civil and Environmental Engineering, The University of New South Wales, Sydney, Australia, 2018.

[34] B. Piscesa, M. Attard, A. Samani, and S. Tangaramvong, "Plasticity Constitutive Model for Stress-Strain Relationship of Confined Concrete," ACI Structural Journal, vol. 114, no. 2, p. 361, 2017.

[35] B. Piscesa, M. M. Attard, D. Prasetya, and A. K. Samani, "Modeling cover spalling behavior in high strength reinforced concrete columns using a plasticity-fracture model," Engineering Structures, vol. 196, p. 109336, 2019.

[36] B. Piscesa, M. M. Attard, and A. K. Samani, "A lateral strain plasticity model for FRP confined concrete," Composite Structures, vol. 158, pp. 160-174, 2016.
[37] B. Piscesa, "Numerical Investigation on The Behaviour of Concrete-Filled-Steel-Tube Column under Eccentric Loading," presented at the The Third International Conference on Civil Engineering Research (ICCER), Surabaya, Indonesia, 1-2 August 2017,, 2017.

[38] The Open Source Integration Platform for Numerical Simulation. (2017). http://www.salome-platform.org/. [Online]. Available: http://www.salome-platform.org/

[39] N. Bunni, B. Scott, R. Park, and M. Priestley, "Stress-strain behavior of concrete confined by overlapping hoops at low and high-strain ratesdiscussion," Journal of the American Concrete Institute, vol. 79, no. 6, pp. 496-498, 1982.

[40] A. Fam, B. Flisak, and S. Rizkalla, "Experimental and analytical modeling of concrete-filled FRP tubes subjected to combined bending and axial loads," ACI Struct. J, vol. 100, no. 4, pp. 499-509, 2003.

[41] T. Yu, Y. Wong, and J. Teng, "Behavior of hybrid FRP-concrete-steel double-skin tubular columns subjected to eccentric compression," Advances in Structural Engineering, vol. 13, no. 5, pp. 961974, 2010.

[42] B. Csuka and L. P. Kollár, "Analysis of FRP confined columns under eccentric loading," Composite Structures, vol. 94, no. 3, pp. 11061116, 2012. 